\title{
Multiscale Fracture Analysis in a Reservoir-Scale Carbonate Platform Exposure (Sorrento Peninsula, Italy): Implications for Fluid Flow
}

\author{
L. Massaro $\mathbb{D}$, A. Corradetti, F. Vinci $(\mathbb{D})$, S. Tavani, A. Iannace, M. Parente, and S. Mazzoli $\mathbb{D}$ \\ DiSTAR, Università degli Studi di Napoli Federico II, Naples, Italy \\ Correspondence should be addressed to S. Mazzoli; stefano.mazzoli@unina.it
}

Received 2 July 2017; Revised 4 January 2018; Accepted 9 January 2018; Published 7 February 2018

Academic Editor: Wei Wu

Copyright (C) 2018 L. Massaro et al. This is an open access article distributed under the Creative Commons Attribution License, which permits unrestricted use, distribution, and reproduction in any medium, provided the original work is properly cited.

We derive the discrete fracture network (DFN) of a Lower Cretaceous carbonate platform succession exposed at Mt. Faito (Southern Apennines), which represents a good outcrop analogue of the coeval productive units of the buried Apulian Platform in the Basilicata oilfields. A stochastic distribution of joints has been derived by sampling at two different scales of observation. At the outcrop scale, we measured fracture attributes by means of scan lines. At a larger scale, we extracted fracture attributes from a 3D model. This multiscale survey showed the occurrence of an arresting bed for through-going fractures, which is characterized by a low relative permeability, determining a vertical compartmentalization. The DFN model, obtained by integrating fieldwork and numerical modelling by means of the $3 \mathrm{D}$-Move ${ }^{\circledR}$ software, shows a well-defined relationship of permeability and fracture porosity with the relative connectivity of the fracture network. The latter is influenced by the length and aperture and to a lesser extent by the fracture intensity. The permeability distribution obtained for our outcrop analogue can be used to inform modelling of the Basilicata oilfield reservoirs, although the different burial history between the exposed Apennine Platform and the buried Apulian Platform must be taken into account.

\section{Introduction}

The three-dimensional characterization of fracture networks in carbonate reservoirs represents a primary approach to understand the processes of fluid flow. A joint is a fracture along which an extensional displacement occurs (i.e., it is an opening-mode fracture), whereas the shear displacement is zero or negligible $[1,2]$. Joints play a primary role in fluid flow processes, especially in tight reservoir carbonates. Joints length is used to classify them, in relation to bed thickness, in stratabound and nonstratabound fractures. The former are bed confined and show a regular average spacing, defined by the well-known linear relationship with mechanical layer thickness. A preexisting systematic joint can represent, in certain cases, a mechanical layer boundary, which is characterized by a homogeneous rheological behaviour [3]. Nonstratabound joints are longer or shorter with respect to the mechanical layer and show more irregular average spacing trends with respect to the stratabound ones [3-14].
In this study, DFN modelling was performed following a multiscale joint sampling carried out at two different scales of observation: at the mesoscale (i.e., outcrop scale) with the scan line method and at a larger scale performing a photogrammetry analysis with the help of an unmanned aerial vehicle. These two scales were chosen in order to obtain information from the bed scale to the reservoir scale. The former sampling has been focused on fractures from centimetres to few meters length, recording orientation (azimuth and dip), aperture $(\mathrm{mm})$, length $(\mathrm{cm})$, distance from the origin $(\mathrm{cm})$, morphology, filling, and crosscutting relationships. Scan lines have been performed on six beds, with a cumulative length of 20 meters along the outcrop surface. On the other hand, the larger scale survey has been focused on through-going joints, performed by means of an unmanned aerial vehicle as described in Corradetti et al. [15]. Through-going joints are meters and tens of meters-long fractures which, crosscutting several beds, are essential in the linkage of the different fracture systems at 
the reservoir scale providing an important contribution to the permeability. They develop from a series of vertically aligned, subparallel systematic joints that, crosscutting many beds, may form a multilayer brittle structure. These earlier joints can be reactivated and linked by coalescence or through the generation of new fractures that accommodate the linkage of joints forming a zigzag structure [16].

A multiscale approach (i.e., over several scales of observation) has been broadly adopted by many authors ([17] and references therein [18-21]) for reservoir DFN modelling, as it yields a better understanding of the geometry and the relationships between fracture systems affecting the rock volume, which can span from hundreds of meters of length down to the smaller observable scale. At the outcrop scale, where bedding plays a primary role and usually defines mechanical layer boundaries, the stratabound fracture systems are the principal target of the scan line survey. On the other hand, nonstratabound fractures form the principal discontinuity system at larger scales. According to many authors [12, 14], a fracture network can be described as a hierarchical organization of permeable structures, including the fault network, stratabound fracture systems, nonstratabound fracture systems, and the nonfractured host rock, which hydraulically interact with each other.

The studied outcrop is located in the Lattari Mts, within the Sorrento Peninsula, a ridge mainly made of TriassicCenozoic shallow-water carbonates [22-27]. The analysis has been focused on a package of six beds belonging to a Barremian-Lower Aptian shallow-water carbonate succession [28] cropping in the SW slope of Mt. Faito. Previous studies focused on these carbonates because of their analogies (in terms of age, lithology, facies, texture, and mechanical layers thickness) with the Val D'Agri and Tempa Rossa reservoir units of the Basilicata region [14, 15, 27-32]. These oil reservoirs are trapped within the buried Apulian Platform carbonates by broad antiform folds deriving from thick-skinned inversion [33-35]. Mechanical and stratigraphic results from outcropping analogues could provide an important tool to understand fluid flow processes in the reservoirs, although the different burial depth conditions must be considered.

\section{Geological Setting}

The southern Apennines is a NE-vergent fold and thrust belt derived from the collision between the Adria and Eurasiatic plates, which started in the Early Miocene (e.g., Cello and Mazzoli, 1999). The paleogeographic reconstruction, before subduction, shows an alternation of platforms and basins, including the Apennine Platform and the Apulian Platform separated by the Lagonegro Basin ([37] and references therein). The Apennine chain is characterized by two main components: (i) the Apennine accretionary wedge and (ii) the buried Apulian Platform Inversion Belt (APIB) [34, 38]. The former consists of Mesozoic-Paleogene pelagic basin successions and platform carbonates covered by Neogene foredeep and thrust-top basin sediments. The basement underlying the APIB is involved in thrusting [33], and a shortening of $14-25 \mathrm{~km}$ characterizes the Apulian Platform unit $[37,39]$.
The studied succession, belonging to the Apennine Platform unit, crops along the SW slope of the Mt. Faito, in the Mt. Lattari mountain group (Figure 1). The latter is characterized mainly by the presence of Mesozoic shallow-water carbonate successions, which form on the Amalfi side steeper cliffs with respect to the Sorrento side. These carbonate platforms tectonically overlay a pile of Mesozoic-Tertiary pelagic basin successions belonging to the Lagonegro unit, Neogene flysch deposits, and shallow-water and slope facies carbonates of the Apulian Platform ([40-43] and references therein). The analysed carbonate succession, cropping out for almost 600 meters, is composed of upper Valanginian-Albian limestones and dolostones with internal platform to lagoon margin facies [23]. The examined beds, subhorizontal and N-dipping, belong to the interval "C" and represent a Barremian-Lower Aptian succession about 160 meters thick, mainly calcareous with some dolomite caps. This interval records a transgressive trend to more open marine facies [28].

Early diagenetic dolomitization generated different types of dolomite, named "dolomite A" and "dolomite B" [26$28,44]$. The former is characterized by smaller crystal size $(10-50 \mu \mathrm{m})$ and low porosity grade; the latter shows a larger crystal size $(70-130 \mu \mathrm{m})$ and variable porosity grade [32, 44]. These processes can intensely modify the porosity, forming dolostone levels more porous with respect to the precursor limestone.

\section{Fracture Sampling}

The analysed succession shows the presence of three joint sets (Figure 2) striking ENE-WSW (set 1), ESE-WNW (set 2), and NNE-SSW (set 3). Because of the poor accessibility of outcrops and their different exposure, surveys have been focused on two different joint sets, "set 1 " for field measurements and "set 3 " for the digital outcrop model. The subsequent reservoir modelling has been performed idealizing the same characteristics, in terms of average spacing, aperture, and length, for through-going joints of set 1 projected onto the same surface of the measured fractures of set 3 . Nevertheless, a multiscale approach allows a good understanding of the geometry of a fracture network affecting the rock volume, minimizing the occurrence of biases relative to a statistical analysis of DFN.

Fractures can be detected at all observable scales, characterized by the well-known fractal property, generating similar patterns at various scales [45]. As a result, fracture density estimates can be strictly dependent on the smallest fracture size measured. To avoid a fracture density overrating and to permit an equal comparison of fracture intensities from different outcrops, it is useful to fix a common minimum fracture aperture [21]. In this work, a logarithmically graduated comparator has been utilized to collect aperture measurements [21] fixing a lower threshold at $0.33 \mathrm{~mm}$ for scan line surveys, with the help of a hand lens.

The statistical analysis of fracture systems can be affected by some uncertainties derived from artifacts of various natures and origins, usually related to joint length. The truncation error concerns smaller fractures, around the limit of resolutions of the observation tool (naked eye, hand lens, 


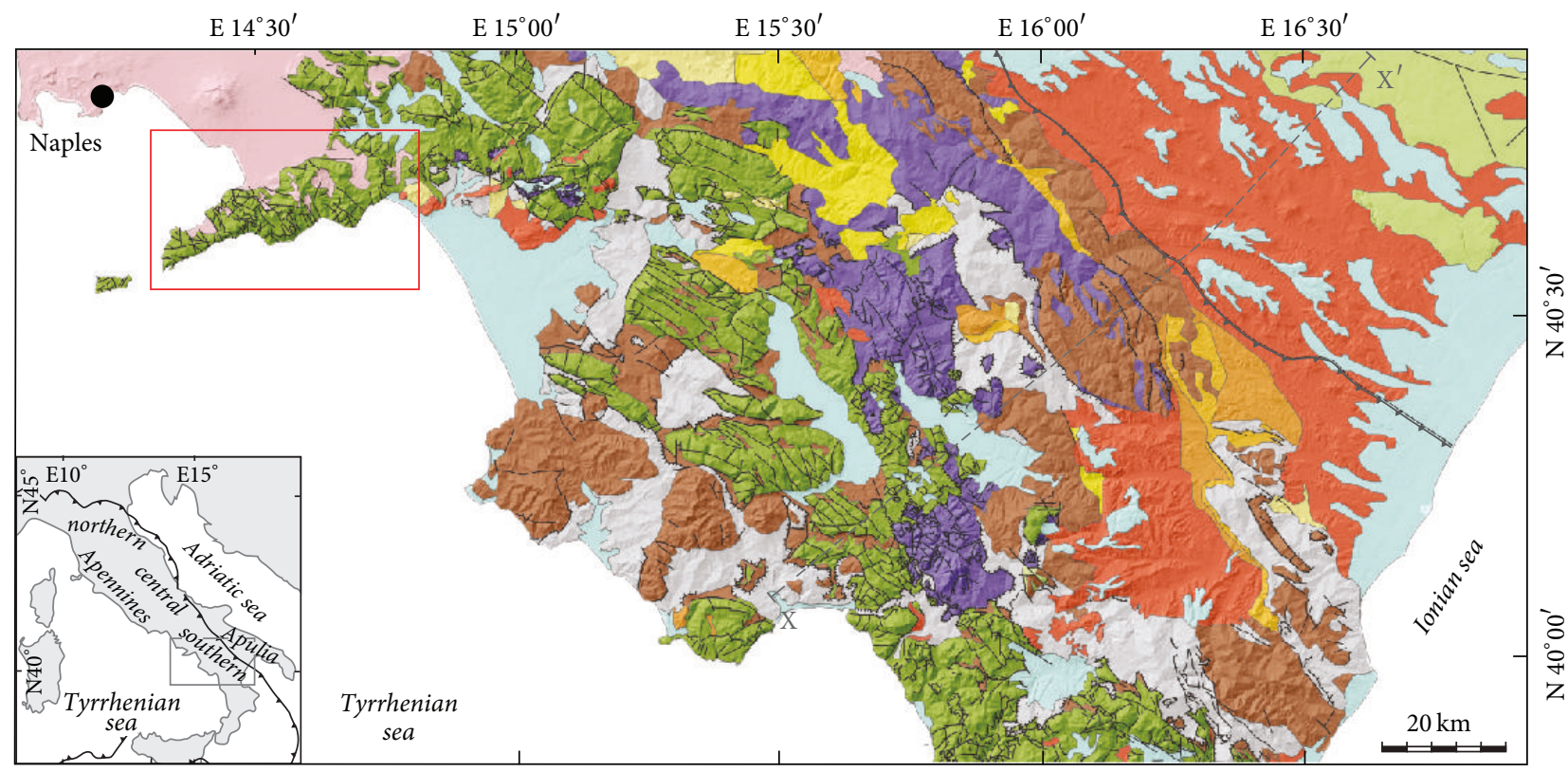

(a)

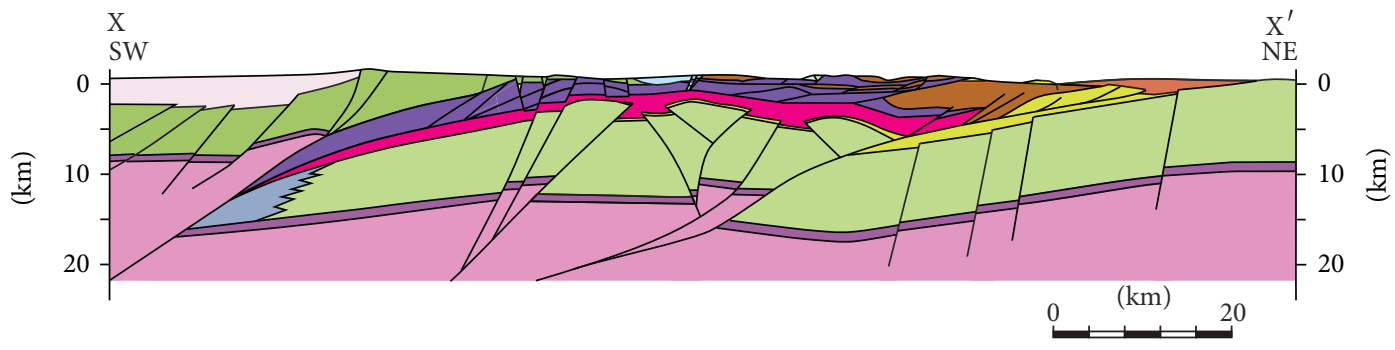

(b)
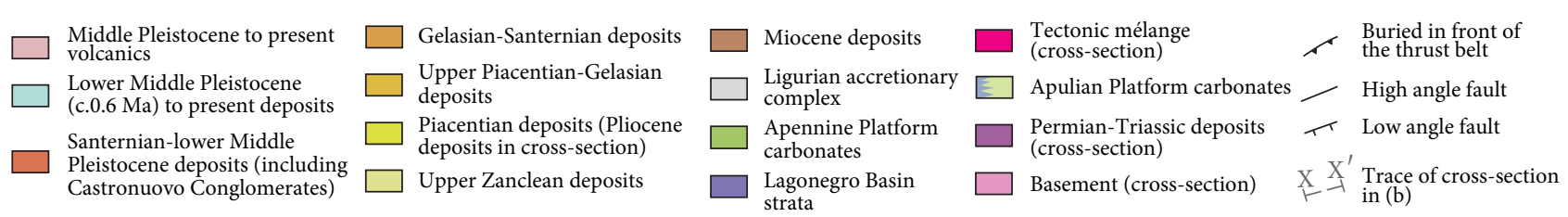

Figure 1: Geological sketch map of the Southern Apennines (after [36]; modified). Red box shows the study area. The regional cross-section $\mathrm{X}-\mathrm{X}^{\prime}$ shows the tectonic unit analysed (Apennine Platform carbonates) and the buried analogue unit (Apulian Platform carbonates).

and optical microscope), and can be minimized fixing a lower threshold size for fracture measurements. Statistical sampling of larger fractures can be affected by censoring and undersampling artifacts. The former occur when joints are longer than the analysed outcrop and cannot be entirely measured; the latter take place because larger joints are typically characterized by higher spacing values influencing sampling probabilities and, consequently, require very long scan lines to collect an adequate number of fractures for a statistical sampling. To bypass both errors and reduce uncertainties, multiscale sampling is essential [21].

3.1. Unmanned Aerial Vehicle. The larger scale survey has been performed by means of an unmanned aerial vehicle
(UAV [46-49]), commonly referred to as a drone, equipped with a mirrorless photo-camera, generating a 3D model after a photogrammetric analysis that yields the definition of a clear mechanical stratigraphy for large-scale fracture corridors. These joints, reaching tens of meters of length, play an important role in the processes of fluid flow in a reservoir, linking together different fracture systems, otherwise isolated to each other. The 3D model of the Conocchia cliff has been performed using the Agisoft PhotoScan software, building up a Virtual Outcrop Model (VOM) derived by the superimposition of multiple images of the same outcrop, accomplished with large overlaps to avoid the resulting of uncovered areas, acquired from different points of view. Subsequently, the obtained VOM has been scaled and georeferenced by means 


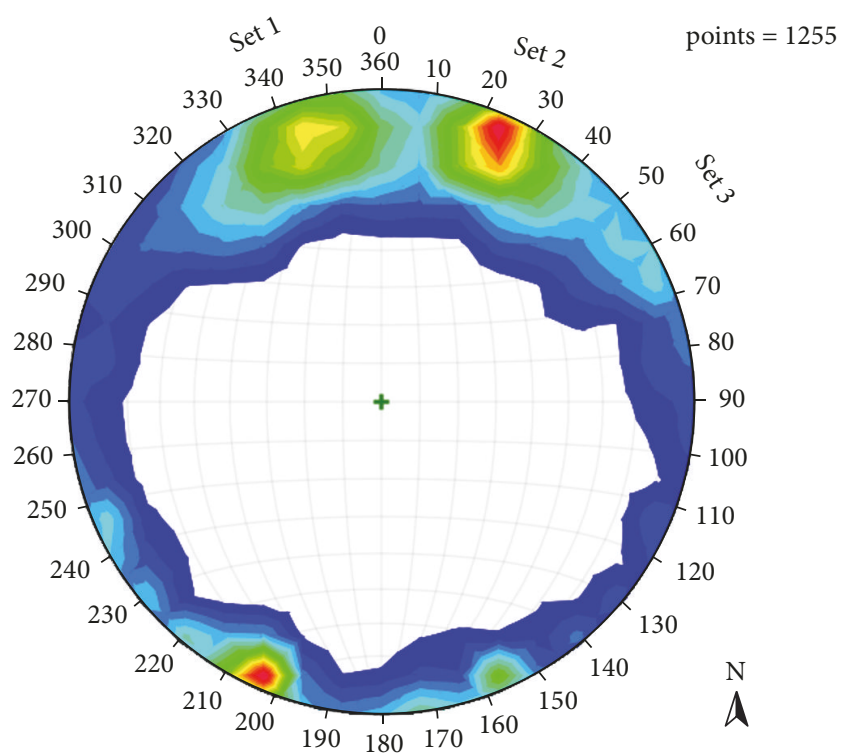

FIGURE 2: Orientation data (lower hemisphere, equal-area projection of poles to planes) of all joint sets measured by the two surveys carried out at different scales.

of various points with known coordinates (Ground Control Points, CGPs). Such a model has been then analysed with the open source software OpenPlot $[50,51]$ in order to identify and digitize the geological structure of interest, namely, joints and bedding surfaces, not considering smaller fractures below the meter scale because of the model resolution but focusing on meters and tens of meters-long through-going fractures.

Because of the outcrop exposure and the relative fracture sets orientations, only "set 3" (Figure 2), normal to the outcrop, has been considered for spacing analysis, whereas the evaluation of fracture terminations includes all the sets. This latter analysis, after the digitization of bedding surfaces and through-going joints, identified the presence of two mechanical boundaries particularly efficient to impede through-going propagation, showing a fracture impedance of about 99\% (Figure 3), whereas other mechanical boundaries of the succession show fracture impedance ranging between $20 \%$ and $60 \%$ [15].

3.2. Fracture Analysis Using the Scan Line Method. The observations carried out from the larger scale survey pointed out the basis for the outcrop-scale survey, which has been focused on a package of beds (Figure 4(a)) around one of the aforementioned mechanical barriers that impede throughgoing fractures propagation. This latter is represented by a $43 \mathrm{~cm}$ thick dolomitic bed (Figure $4(\mathrm{~b})$ ) characterized by a thin pseudo-stratification with internal levels of about $2 \mathrm{~cm}$ of thickness, sandwiched between thicker calcareous beds.

Six scan lines have been carried out on six carbonate beds (Figure 4(a)) with different thickness: C1-59 (dolostone, $71 \mathrm{~cm}$ ), C2-3 (wackestone-packstone, $33 \mathrm{~cm}$ ), $\mathrm{C} 2-5$ (wackestone-packstone, $26 \mathrm{~cm}$ ), C2-6 (dolostone, $43 \mathrm{~cm}$ ), C2-7 (partially dolomitized limestone, $21 \mathrm{~cm}$ ), and $\mathrm{C} 2-8$

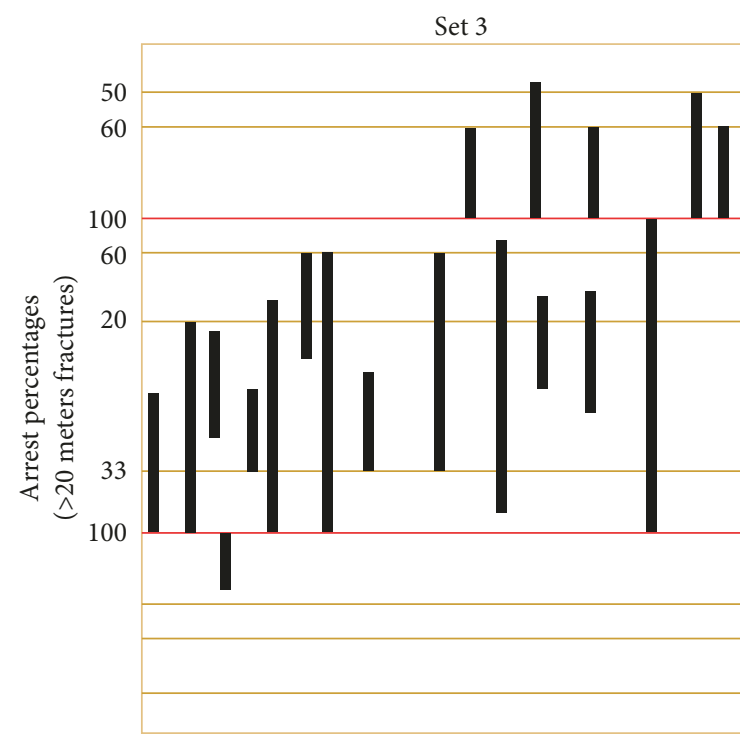

FIgURE 3: Set 3-joint digitalization and identification of throughgoing fractures and major mechanical boundaries (from [15]).

(wackestone-packstone, $47 \mathrm{~cm}$ ) (Figure 4(a)). The bed C2-6 is characterized by a continuous pseudo-stratification, showing internal levels with 1-2 cm thickness (Figure 4(b)).

Joints length $(\mathrm{cm})$, aperture $(\mathrm{mm})$, distance from the origin $(\mathrm{cm})$, azimuth, dip, morphology, crosscutting relationships, and filling have been collected. Joint aperture has been recorded with a logarithmically graduated comparator proposed by Ortega et al. [21]. Because of the outcrop orientation and the relative fracture systems exposition, only "set 1" (Figure 2), normal to the outcrop, has been collected. After the sampling, in order to define the statistical distribution of the fracture properties in each bed, it is important to treat the stratabound and nonstratabound joints separately.

\section{Modelling}

DFN modelling has been performed with the software Move, a complete structural geology toolkit developed by the Scottish company, Midland Valley. A basic "GeoCellular Volume" represents the six beds analysed (Figure 5), to which some geological intrinsic parameters have been assigned to characterize them, such as lithology, porosity (\%) (from [32]), average density $\left(\mathrm{g} / \mathrm{cm}^{3}\right)$, Young modulus $(\mathrm{MPa})$, and Poisson ratio [52].

After this preliminary stage, fracture networks have been defined for each bed combining the results carried out through the two-scale surveys performed. The software allows one to obtain a stochastic distribution of more discrete fracture networks (Figure 6) defining a series of parameters relative to the fracture system: fracture intensity, length, azimuth, dip, $K$-Fisher value, aspect ratio, and aperture. Fracture intensity is defined by the parameter " $N$ " (Table 1), number of fractures per volume unit, calculated for each set after a trigonometric correction relative to beds orientation based on Terzaghi [53]. 


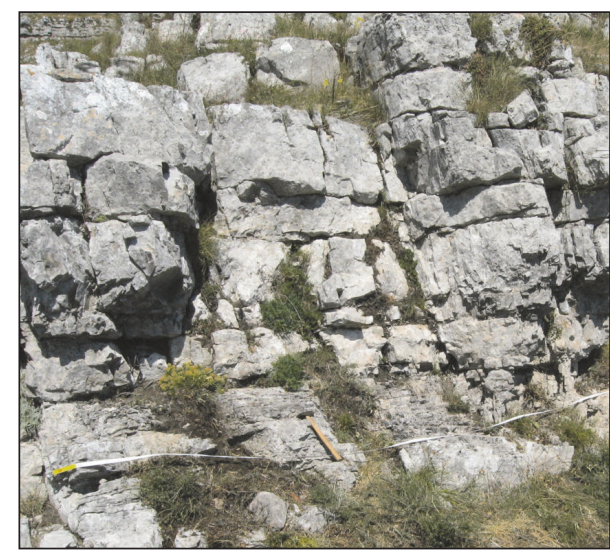

(a)

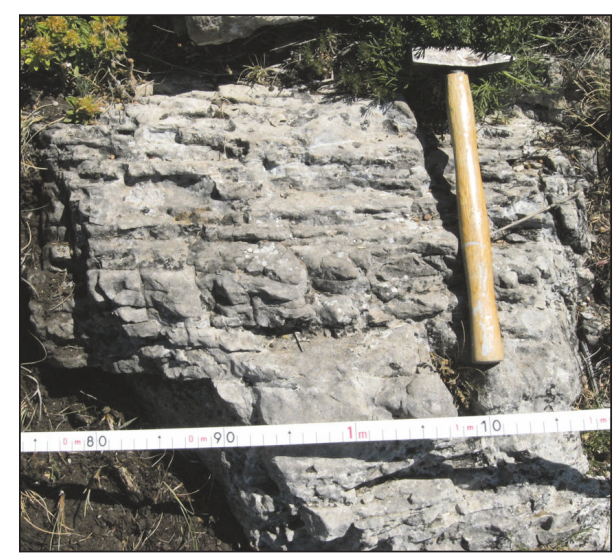

(b)

FIGURE 4: Field photographs showing (a) the outcrop analysed through the scan line method and (b) the C2-6 bed.

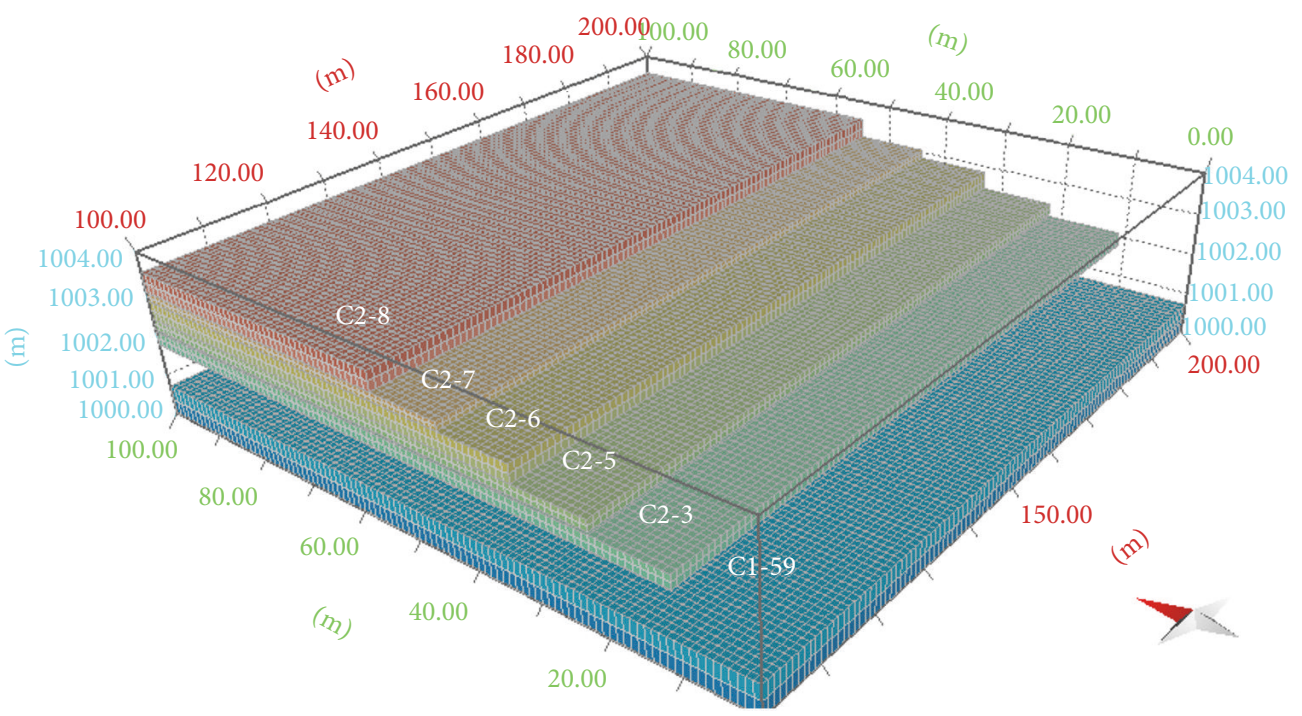

FIGURE 5: Basic GeoCellular Volume $\left(10000 \mathrm{~m}^{2}\right.$ at the base and height proportional to the measured layer thickness) representing the six analysed beds (the model is staircase shaped to allow a clear visualization of each bed).

The " $K$ Fisher value" is a parameter derived from the joints stereographic distribution for each set and describes how much they are clustered. After modelling the DFNs, the software allows us to analyse the network connectivity and some related parameters such as secondary porosity $(\%)$, permeability $(D)$, sigma factor, block size $\left(\mathrm{m}^{3}\right)$, P32 $\left(\mathrm{m}^{2} / \mathrm{m}^{3}\right)$, and anisotropy (\%). Porosity is calculated for a given cell as the ratio of total fracture volume in a cell per cell volume. Permeability calculation is based on the geometric methodology described by Oda [54], which itself is based on Darcy's Law (see (1)) and the laminar flow theory between parallel plates:

$$
\frac{Q}{A}=\frac{s^{3}}{12 D} \frac{\delta h}{\delta l} \frac{\rho g}{\mu}
$$

where $Q$ is the total discharge, $A$ is the cross-sectional area to flow, $s$ is the joint aperture, $D$ is the spacing, $\delta h / \delta l$ is the hydraulic gradient, $\rho$ is the fluid density, and $\mu$ is the dynamic viscosity.

Sigma factor is calculated following the multidirectional algorithm described in LaPointe [55]. Three rays are created for each cell, each having a source that is the centre of the face and a target that is the opposite face of the cell. For each fracture in the cell that intersects along the ray, average intersection spacing is calculated. The value of sigma can then be calculated by the following equation [55]:

$$
\sigma=0.25\left(\frac{1}{X^{2}}+\frac{1}{Y^{2}}+\frac{1}{Z^{2}}\right) .
$$

Block size is defined by the average intersection spacing along a ray as described for the sigma factor. Both the sigma factor and the block size define the fracture intensity of the rock volume. P32 $\left(\mathrm{m}^{2} / \mathrm{m}^{3}\right)$ also describes the fracture density and represents the ratio between the total area of fractures per volume unit. 
TABLE 1: Fracture intensity " $N$ " for each analysed bed.

\begin{tabular}{lc}
\hline Bed & $N$ \\
\hline C1-59 & 12.687 \\
C2-3 & 4.554 \\
C2-5 & 0.354 \\
C2-6 & 14.351 \\
C2-7 & 7.603 \\
C2-8 & 14.305 \\
\hline
\end{tabular}

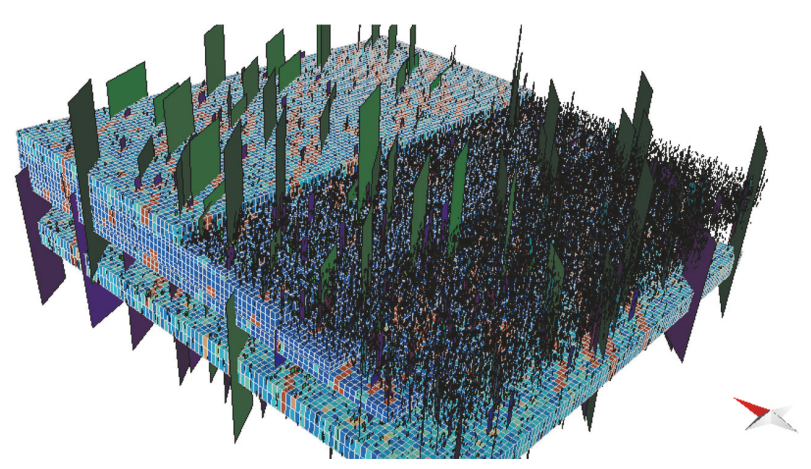

Figure 6: Discrete fracture network model $\left(10000 \mathrm{~m}^{2}\right.$ at the base and height proportional to the measured layer thickness) populated with analysed fractures for each bed.

\section{Discussion}

In this work, a reservoir DFN modelling has been carried out by means of a statistical sampling performed with a multiscale approach, analysing a fractured carbonate succession located in the Sorrento Peninsula, which represents a good analogue of buried reservoir units of southern Italy major's oil fields. The fracture modelling carried out with the software Move allowed us to simulate the natural fracture network and to obtain information on porosity and permeability, also taking into account the petrophysical properties of the matrix. A first approach to fracture modelling has been focused on the background joints, considering only fractures measured by means of scan lines in the field and analysing the related permeability distribution. This model (Figure 7) shows two beds with high, two with medium, and two with low relative permeability. A comparison between this model and fracture characteristics recorded by means of scan lines in the field (Figure 8) emphasises some aspects relative to the generated output properties. Beds C1-59, C2-6, and C28 are more intensely fractured with respect to the others; however, despite this evidence, bed C2-6 appears like a relative impermeable level, whereas beds C1-59 and C2-8 are more permeable (Figure 7 ). This result outlines the relative importance of joints characteristics in terms of fluid flow processes. Joint aperture and length are both fundamental parameters in terms of permeability, as described in Darcy's Law (see (1)). As a matter of fact, bed C2-6 is characterized by lower values of average fracture spacing but also has lower values of aperture and length with respect to the other analysed beds (Figure 7). On the other hand, bed C2-5 shows
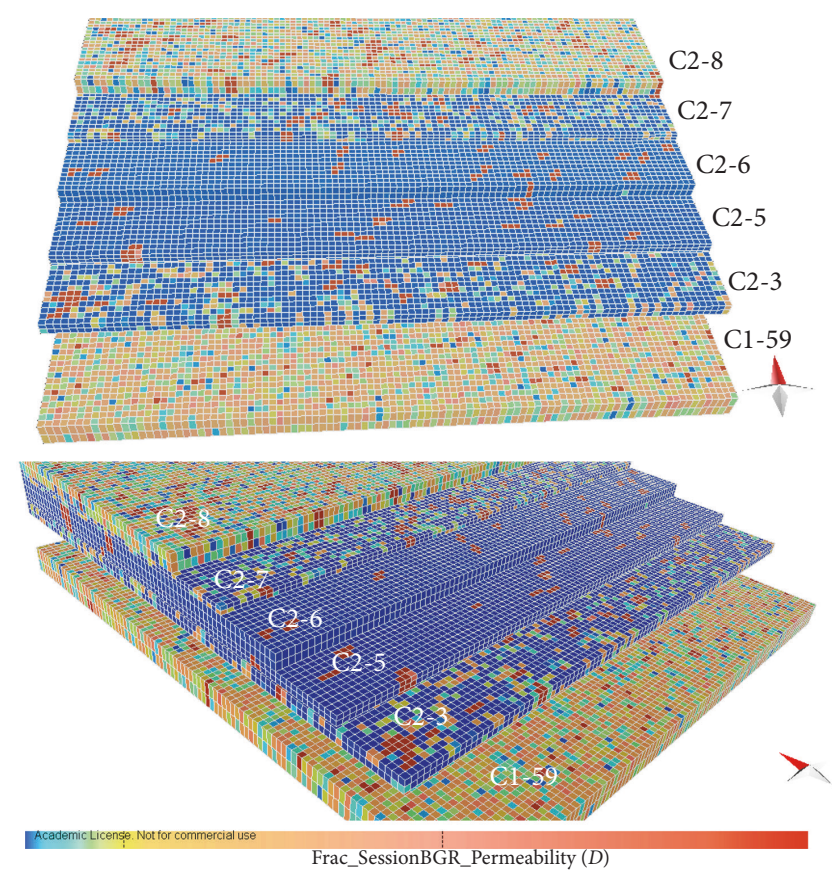

Figure 7: Background fracture model $\left(10000 \mathrm{~m}^{2}\right.$ at the base and height proportional to the measured layer thickness) showing relative permeability $(D)$.

high values of length and aperture but has a low relative permeability values because of his higher average fracture spacing values.

The model in Figure 9 comprises fractures detected by both surveys at different scales. Permeability distribution points out the occurrence of a level of low relative permeability represented by bed C2-6, whereas beds C1-59 and C28 are the most permeable ones. The primary role played by through-going fractures is evidenced by this model, being testified by many vertical, high permeability zones affecting each layer, except for bed C2-6. In this case, bed C2-5 increases its relative permeability, showing a clear alternation of low and high permeability zones, the former resulting from its poor background jointing and the latter representing a consequence of the through-going joints crosscutting the bed.

Other output properties are shown in Figure 10 and all of them confirm the aforementioned trends remarked for both the relative permeability and background jointing models. Beyond these observations, these models confirm that a primary feature that determines the lowest permeability of bed C2-6 is represented by the high impedance of this level with respect to through-going joints detected by the largescale (i.e., virtual outcrop) survey.

According to Gross and Eyal [16], through-going joints develop by progressive linkage of preexisting fractures. Stratabound joint systems play a fundamental role in this process, as they provide preexisting structures available to be linked with each other or to be reopened, in order to accommodate the stress propagation. As a result of the wellknown linear relationship between stratabound joint spacing 

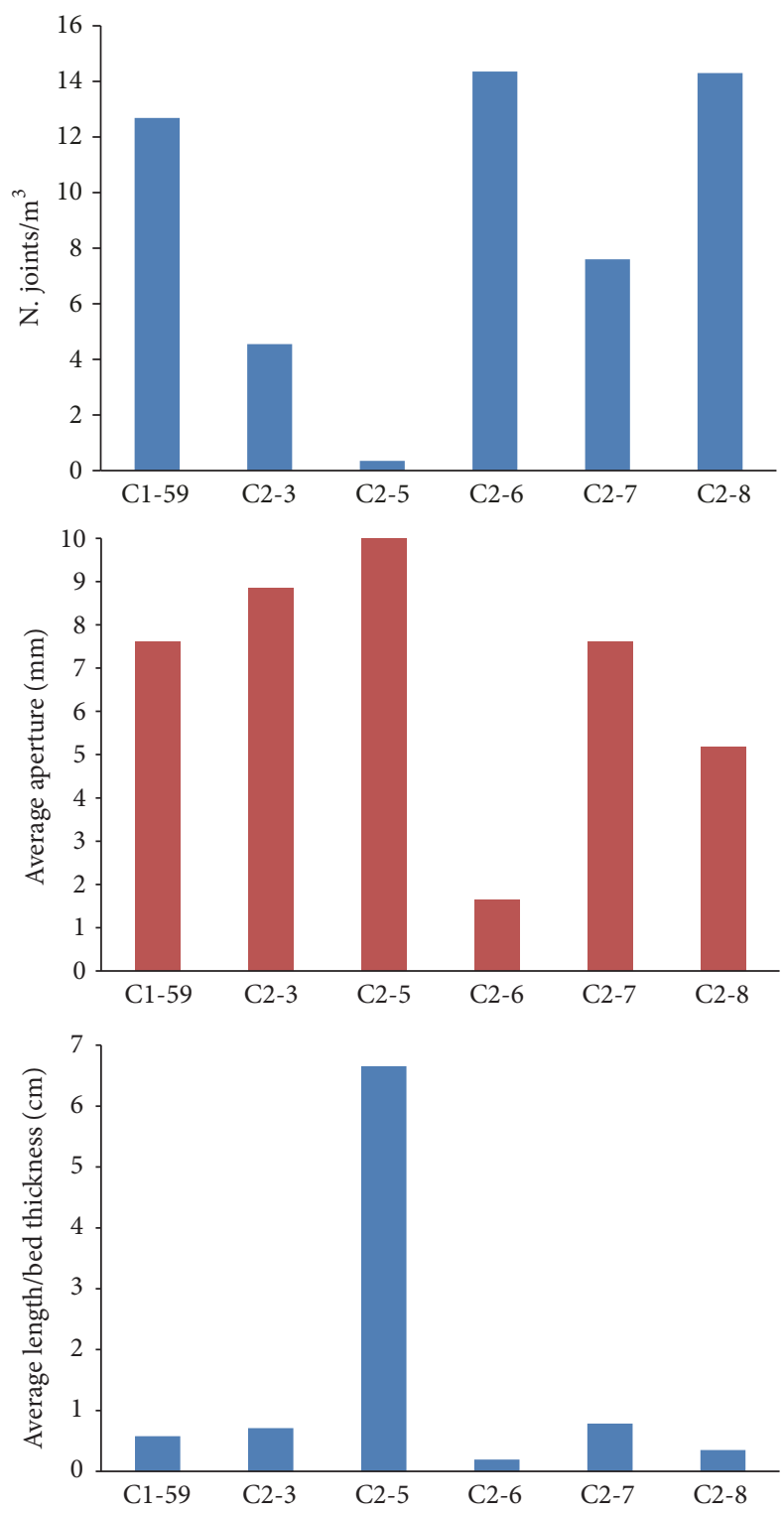

Figure 8: Joints features recorded with the scan line method.

and mechanical layer thickness, thinly bedded layers have a higher probability to present a preexisting joint at any given position with respect to a thicker one. In this way, during the through-going joint propagation stage, the stress perturbation area tends to develop new joints in thicker beds [56], whereas it splays in various preexisting joints in thinly stratified beds. As a consequence, the formation of new joints and the linkage of preexisting ones produce a more linear and continuous through-going structure in thicker beds, while thinly bedded layers like unit C2-6 of this study behave as impedance levels.

\section{Conclusions}

In this work, we proposed DFN modelling using the software Move 2016 following a statistical sampling performed with a multiscale approach. A larger scale survey allowed us to
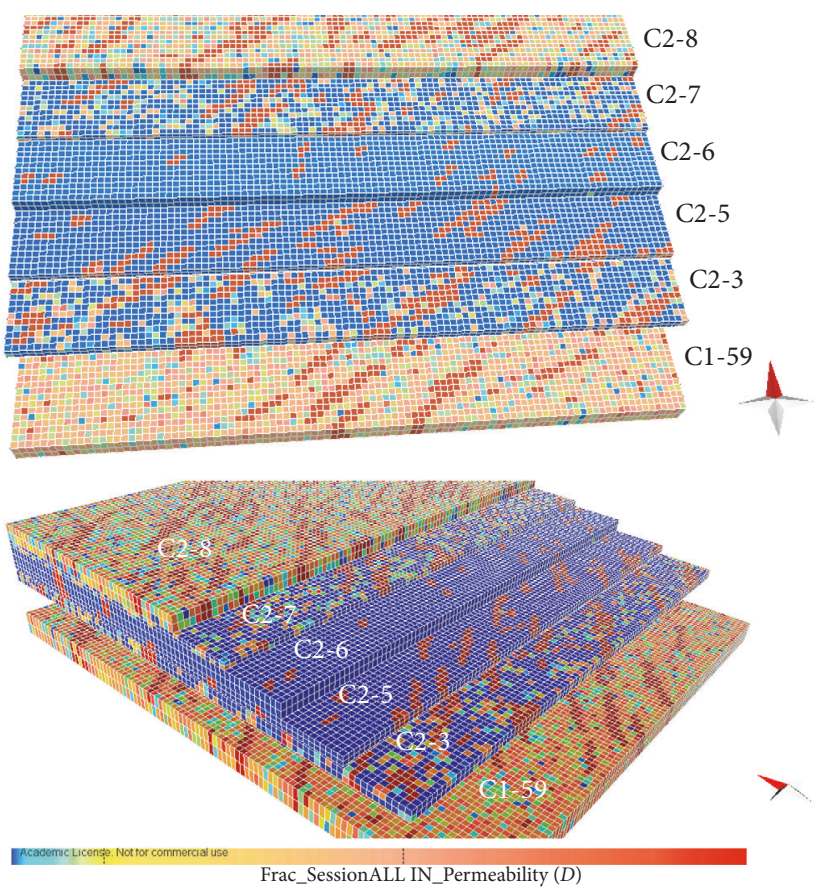

FIGURE 9: Final model $\left(10000 \mathrm{~m}^{2}\right.$ at the base and height proportional to the measured layer thickness) of relative permeability $(D)$ associated with fractures studied at the two scales of observations.

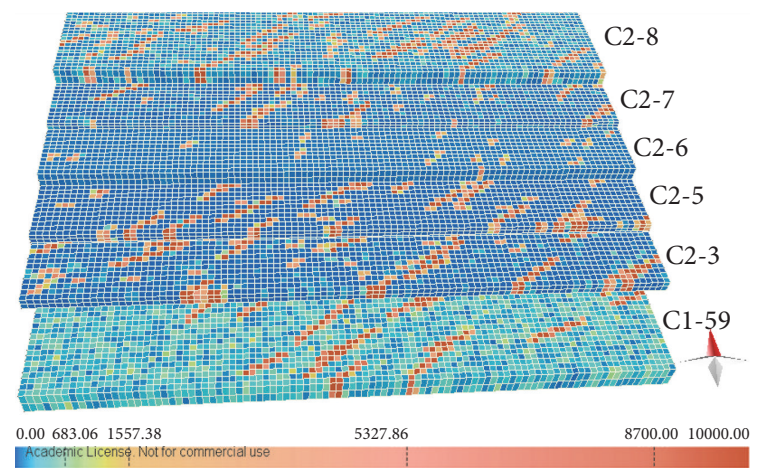

Frac_SessionALL IN_Porosity (\%)

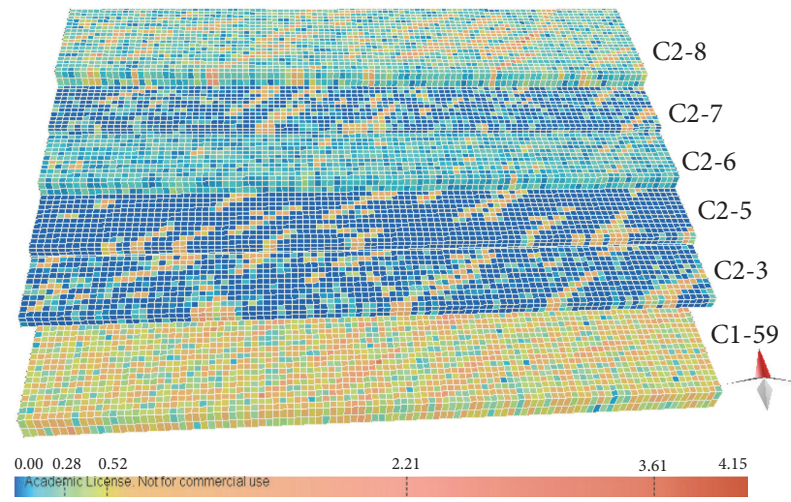

Frac_SessionALL IN_P32 $\left(\mathrm{m}^{2} / \mathrm{m}^{3}\right)$

Figure 10: Final model $\left(10000 \mathrm{~m}^{2}\right.$ at the base and height proportional to the measured layer thickness) of (a) relative porosity (\%) and (b) P32 $\left(\mathrm{m}^{2} / \mathrm{m}^{3}\right)$. 
identify a mechanical barrier relative to through-going joints. The latter are reservoir-scale, meters to tens of meters-long fractures that play a primary role in fluid flow processes, connecting isolated fracture systems through many beds and guaranteeing, in this manner, vertical linkage throughout the reservoir. The critical level forming a mechanical barrier for through-going joints has been examined by means of an outcrop-scale survey. It corresponds to a $43 \mathrm{~cm}$ thick dolostone bed, named C2-6, characterized by inner pseudolevels of $1-2 \mathrm{~cm}$ thickness. Subsequently, DFN modelling has been performed integrating the data gathered at both scales of observations, obtaining a final 3D model that identified a relative permeability barrier, represented by bed C2-6. This, although showing a high fracture density (Figure 7), has low porosity and permeability (Figures 8 and 9 ) because of the low values of aperture and length associated with the thin pseudo-stratification affecting this dolostone layer, which could therefore provide a vertical compartmentalization of the reservoir.

The knowledge obtained from the final model provides useful insights into the understanding of the processes of fluid flow in carbonate reservoirs, although the different burial conditions and tectonic evolution of the analysed Apennine Platform with respect to the buried Apulian Platform productive units have to be taken into account.

\section{Conflicts of Interest}

The authors declare that they have no conflicts of interest.

\section{Acknowledgments}

Move software, for which Midland Valley Ltd. is gratefully acknowledged, was used for discrete fracture network modelling (academic license available to the University of Naples Federico II).

\section{References}

[1] K. R. McClay, The Mapping of Geological Structures, Open University Press, Maidenhead, UK, 1987.

[2] J. G. Ramsay and M. I. Huber, The Techniques of Modern Structural Geology, vol. 2, Academic Press, London, UK, 1987.

[3] M. R. Gross, “The origin and spacing of cross joints: examples from the Monterey Formation, Santa Barbara Coastline, California," Journal of Structural Geology, vol. 15, no. 6, pp. 737-751, 1993.

[4] N. J. Price, Fault and Joint Development in Brittle and Semibrittle Rocks, Pergamon Press, Oxford, UK, 1966.

[5] Q. Huang and J. Angelier, "Fracture spacing and its relation to bed thickness," Geological Magazine, vol. 126, no. 4, pp. 355-362, 1989.

[6] W. Narr and J. Suppe, "Joint spacing in sedimentary rocks," Journal of Structural Geology, vol. 13, no. 9, pp. 1037-1048, 1991.

[7] N. Mandal, S. K. Deb, and D. Khan, "Evidence for a non-linear relationship between fracture spacing and layer thickness," Journal of Structural Geology, vol. 16, no. 9, pp. 1275-1281, 1994.

[8] M. R. Gross and T. Engelder, "Strain accommodated by brittle failure in adjacent units of the Monterey Formation, U.S.A.: scale effects and evidence for uniform displacement boundary conditions," Journal of Structural Geology, vol. 17, no. 9, pp. 13031318, 1995.

[9] H. Wu and D. D. Pollard, "An experimental study of the relationship between joint spacing and layer thickness," Journal of Structural Geology, vol. 17, no. 6, pp. 887-905, 1995.

[10] W. Narr, "Estimating average fracture spacing in subsurface rock," AAPG Bulletin, vol. 80, no. 10, pp. 1565-1586, 1996.

[11] C. Pascal, J. Angelier, M.-C. Cacas, and P. L. Hancock, "Distribution of joints: Probabilistic modelling and case study near Cardiff (Wales, U.K.)," Journal of Structural Geology, vol. 19, no. 10, pp. 1273-1284, 1997.

[12] N. E. Odling, P. Gillespie, B. Bourgine et al., "Variations in fracture system geometry and their implications for fluid flow in fractured hydrocarbon reservoirs," Petroleum Geoscience, vol. 5, no. 4, pp. 373-384, 1999.

[13] T. Bai and D. D. Pollard, "Fracture spacing in layered rocks: A new explanation based on the stress transition," Journal of Structural Geology, vol. 22, no. 1, pp. 43-57, 2000.

[14] V. Guerriero, S. Mazzoli, A. Iannace, S. Vitale, A. Carravetta, and C. Strauss, "A permeability model for naturally fractured carbonate reservoirs," Marine and Petroleum Geology, vol. 40, no. 1, pp. 115-134, 2013.

[15] A. Corradetti, S. Tavani, M. Parente et al., "Distribution and arrest of vertical through-going joints in a seismic-scale carbonate platform exposure (Sorrento peninsula, Italy): Insights from integrating field survey and digital outcrop model," Journal of Structural Geology, 2017, In press.

[16] M. R. Gross and Y. Eyal, "Throughgoing fractures in layered carbonate rocks," Geological Society of America Bulletin, vol. 119, no. 11, p. 1387, 2007.

[17] E. Bonnet, O. Bour, N. E. Odling et al., "Scaling of fracture systems in geological media," Reviews of Geophysics, vol. 39, no. 3, pp. 347-383, 2001.

[18] O. Bour, P. Davy, C. Darcel, and N. Odling, "A statistical scaling model for fracture network geometry, with validation on a multiscale mapping of a joint network (Hornelen Basin, Norway)," Journal of Geophysical Research: Solid Earth, vol. 107, no. 6, pp. 4-1, 2002.

[19] P. Davy, O. Bour, J.-R. De Dreuzy, and C. Darcel, Geological Society, London, Special Publications, vol. 261, Special Publications, London, UK, 2006.

[20] N. E. Odling, "Scaling and connectivity of joint systems in sandstones from western Norway," Journal of Structural Geology, vol. 19, no. 10, pp. 1257-1271, 1997.

[21] O. J. Ortega, R. A. Marrett, and S. E. Laubach, "A scaleindependent approach to fracture intensity and average spacing measurement," AAPG Bulletin, vol. 90, no. 2, pp. 193-208, 2006.

[22] P. De Castro, "Contributo allo studio dei Mallofagi. Osservazioni sul Menopon pallidum," Bollettino della Società dei naturalisti in Napoli, pp. 3-34, 1962.

[23] J. Robson, "Depositional models for some Cretaceous carbonates from the Sorrento Peninsula," Societ $\alpha$ Geologica Italiana, vol. 40, pp. 251-257, 1987.

[24] A. Iannace, "Caratteri diagenetici dei carbonati di Piattaforma dellAppennino Meridionale e loro implicazioni paleogeografiche," Rivista Italiana di Paleontologia e Stratigrafia, vol. 99, pp. 57-80, 1993. 
[25] G. Carannante, D. Ruberti, and M. Sirna, "Upper Cretaceous ramp limestones from the Sorrento Peninsula (southern Apennines, Italy): Micro- and macrofossil associations and their significance in the depositional sequences," Sedimentary Geology, vol. 132, no. 1-2, pp. 89-123, 2000.

[26] A. Iannace, M. Capuano, and L. Galluccio, “"Dolomites and dolomites" in Mesozoic platform carbonates of the Southern Apennines: Geometric distribution, petrography and geochemistry," Palaeogeography, Palaeoclimatology, Palaeoecology, vol. 310, no. 3-4, pp. 324-339, 2011.

[27] A. Iannace, G. Frijia, L. Galluccio, and M. Parente, "Facies and early dolomitization in Upper Albian shallow-water carbonates of the southern Apennines (Italy): Paleotectonic and paleoclimatic implications," Facies, vol. 60, no. 1, pp. 169-194, 2014.

[28] F. Vinci, A. Iannace, M. Parente, C. Pirmez, S. Torrieri, and M. Giorgioni, "Early dolomitization in the Lower Cretaceous shallow-water carbonates of Southern Apennines (Italy): Clues about palaeoclimatic fluctuations in western Tethys," Sedimentary Geology, vol. 362, pp. 17-36, 2017.

[29] A. Iannace, L. Galluccio, V. Guerriero, S. Mazzoli, M. Parente, and S. Vitale, "Dolomites within the Mesozoic carbonates of Southern Apennines (Italy): Genetic models and reservoir implications," Rendiconti Online Societa Geologica Italiana, vol. 2, pp. 109-114, 2008.

[30] V. Guerriero, A. Iannace, S. Mazzoli, M. Parente, S. Vitale, and M. Giorgioni, "Quantifying uncertainties in multi-scale studies of fractured reservoir analogues: Implemented statistical analysis of scan line data from carbonate rocks," Journal of Structural Geology, vol. 32, no. 9, pp. 1271-1278, 2010.

[31] V. Guerriero, S. Vitale, S. Ciarcia, and S. Mazzoli, "Improved statistical multi-scale analysis of fractured reservoir analogues," Tectonophysics, vol. 504, no. 1-4, pp. 14-24, 2011.

[32] M. Giorgioni, A. Iannace, M. D'Amore et al., "Impact of early dolomitization on multi-scale petrophysical heterogeneities and fracture intensity of low-porosity platform carbonates (Albian-Cenomanian, southern Apennines, Italy)," Marine and Petroleum Geology, vol. 73, pp. 462-478, 2016.

[33] P. Shiner, A. Beccacini, and S. Mazzoli, “Thin-skinned versus thick-skinned structural models for Apulian carbonate reservoirs: Constraints from the Val d'Agri Fields, S Apennines, Italy,' Marine and Petroleum Geology, vol. 21, no. 7, pp. 805-827, 2004.

[34] S. Mazzoli, M. D’Errico, L. Aldega et al., “Tectonic burial and "young" ( $<10 \mathrm{Ma})$ exhumation in the southern Apennines foldand-thrust belt (Italy)," Geology, vol. 36, no. 3, pp. 243-246, 2008.

[35] S. Mazzoli, R. Szaniawski, F. Mittiga, A. Ascione, and A. Capalbo, "Tectonic evolution of Pliocene-Pleistocene wedgetop basins of the Southern Apennines: New constraints from magnetic fabric analysis," Canadian Journal of Earth Sciences, vol. 49, no. 3, pp. 492-509, 2012.

[36] S. Vitale, F. Dati, S. Mazzoli, S. Ciarcia, V. Guerriero, and A. Iannace, "Modes and timing of fracture network development in poly-deformed carbonate reservoir analogues, Mt. Chianello, southern Italy, Journal of Structural Geology, vol. 37, pp. 223235,2012

[37] A. M. Noguera and G. Rea, "Deep structure of the CampanianLucanian Arc (Southern Apennine, Italy)," Tectonophysics, vol. 324, no. 4, pp. 239-265, 2000.

[38] S. Mazzoli, A. Ascione, J. T. Buscher, A. Pignalosa, E. Valente, and M. Zattin, "Low-angle normal faulting and focused exhumation associated with late Pliocene change in tectonic style in the southern Apennines (Italy)," Tectonics, vol. 33, no. 9, pp. 1802-1818, 2014.

[39] R. W. Butler, S. Corrado, S. Mazzoli et al., "Time and space variability of "thin-skinned" and "thick-skinned" thrust tectonics in the Apennines (Italy)," Rendiconti Lincei, vol. 11, no. 1, pp. 5-39, 2000.

[40] S. Mazzoli, S. Barkham, G. Cello et al., "Reconstruction of continental margin architecture deformed by the contraction of the Lagonegro basin, Southern Apennines, Italy," Journal of the Geological Society, vol. 158, no. 2, pp. 309-320, 2001.

[41] R. W. H. Butler, S. Mazzoli, S. Corrado et al., "Applying thickskinned tectonic models to the Apennine thrust belt of Italy Limitations and implications," in Thrust Tectonics and Hydrocarbon Systems: AAPG Memoir 82. AAPG Special Volumes, R. K. McClay, Ed., pp. 647-667, 2004.

[42] A. Ascione, S. Ciarcia, V. Di Donato, S. Mazzoli, and S. Vitale, "The Pliocene-Quaternary wedge-top basins of southern Italy: An expression of propagating lateral slab tear beneath the Apennines," Basin Research, vol. 24, no. 4, pp. 456-474, 2012.

[43] A. Iannace, M. Gasparrini, T. Gabellone, and S. Mazzoli, Late dolomitization in basinal limestones of the southern Apennines fold and thrust belt (Italy). Oil \&amp; Gas Science and Technology e Revue d'IFP Energies Nouvelles 67, 59e75. http://dx.doi .org/10.2516/ogst/2011166.

[44] L. Galluccio, Dolomites within the Mesozoic carbonates of Sorrento Peninsula (Southern Apennines-Italy): Genetic models and reservoirs implications, University of Naples, Naples, Italy, 2009.

[45] J. S. Tchalenko, "Similarities between shear zones of different magnitudes," Bulletin of the Geological Society of America, vol. 81, no. 6, pp. 1625-1640, 1970.

[46] G. Firpo, R. Salvini, M. Francioni, and P. G. Ranjith, "Use of Digital Terrestrial Photogrammetry in rocky slope stability analysis by Distinct Elements Numerical Methods," International Journal of Rock Mechanics and Mining Sciences, vol. 48, no. 7, pp. 1045-1054, 2011.

[47] F. Neitzel and J. Klonowski, Mobile 3D mapping with a low-cost UAV system. Int. Arch. Photogramm. Remote Sens. Spat. Inf. Sci. 38, 1-6.

[48] S. Harwin and A. Lucieer, "Assessing the accuracy of georeferenced point clouds produced via multi-view stereopsis from Unmanned Aerial Vehicle (UAV) imagery," Remote Sensing, vol. 4, no. 6, pp. 1573-1599, 2012.

[49] J. C. Torres, G. Arroyo, C. Romo, and J. De Haro, "3D Digitization using Structure from Motion," in Proceedings of CEIG - Spanish Computer Graphics Conference, I. Navazo and G. Patow, Eds., 2012.

[50] S. Tavani, P. Arbues, M. Snidero, N. Carrera, and J. A. Muñoz, "Open Plot Project: An open-source toolkit for 3-D structural data analysis," Solid Earth, vol. 2, no. 1, pp. 53-63, 2011.

[51] S. Tavani, P. Granado, A. Corradetti et al., "Building a virtual outcrop, extracting geological information from it, and sharing the results in Google Earth via OpenPlot and Photoscan: An example from the Khaviz Anticline (Iran)," Computers of Geosciences, vol. 63, pp. 44-53, 2014.

[52] A. Iannace, S. Mazzoli, M. Parente et al., Integrated characterization of middle Cretaceous dolomitized limestones of the Sorrento Peninsula: an analogue for the Val d'Agri reservoirs, Università di Napoli Federico II internal report, 2007.

[53] R. D. Terzaghi, "Sources of errors in joint surveys," Geotechnique, vol. 15, pp. 287-304, 1965.

[54] M. Oda, "Permeability tensor for discontinuous rock masses," Géotechnique, vol. 35, no. 4, pp. 483-495, 1985. 
[55] P. R. LaPointe, Reservoir Compartmentalization. http://www .fracturedreservoirs.com/niper/database/REPORTS/RES_CHAR/ 0212PRL1.htm.

[56] A. Becker and M. R. Gross, "Mechanism for joint saturation in mechanically layered rocks: An example from southern Israel," Tectonophysics, vol. 257, no. 2-4, pp. 223-237, 1996. 

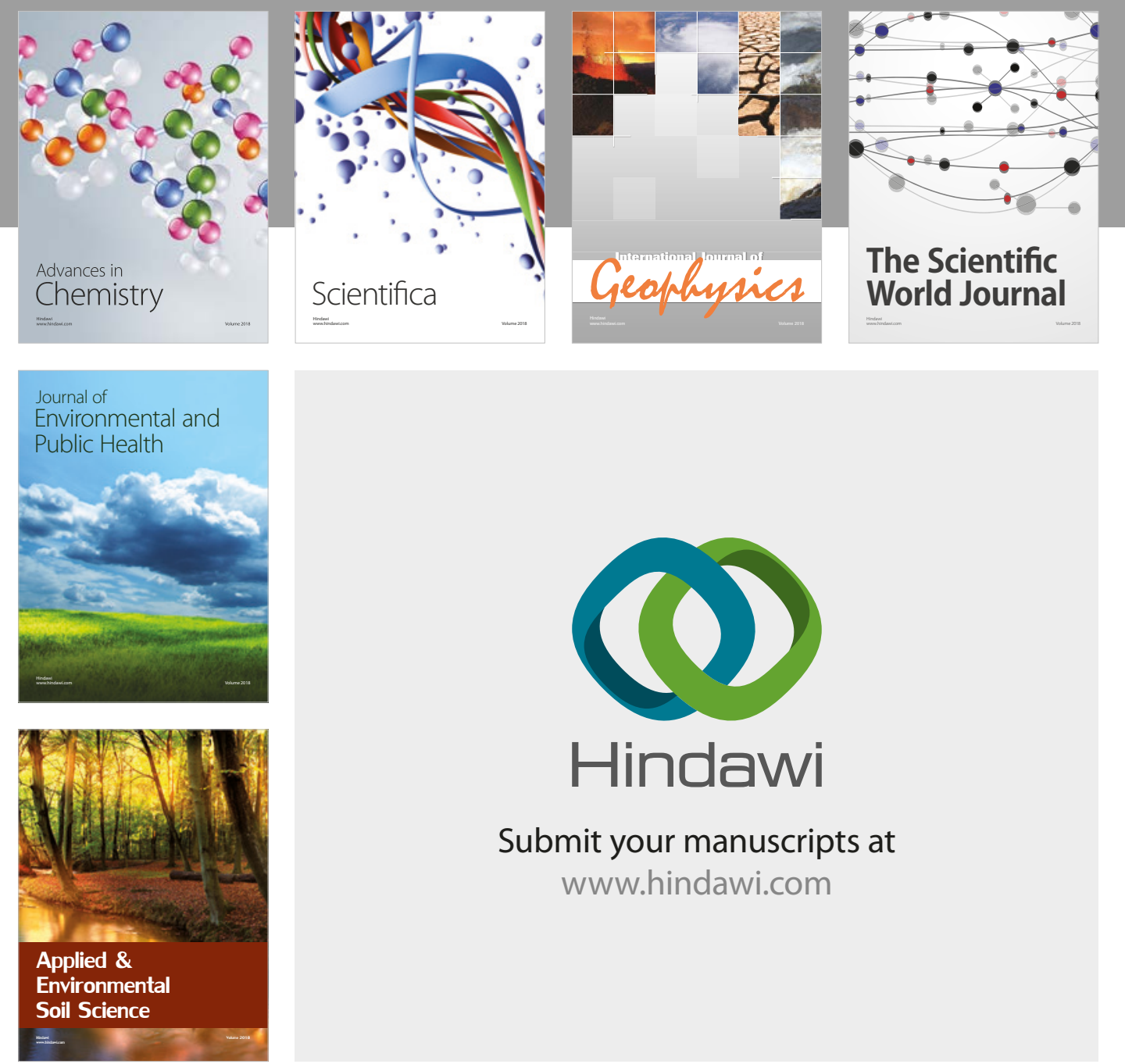

The Scientific

\section{World Journal}
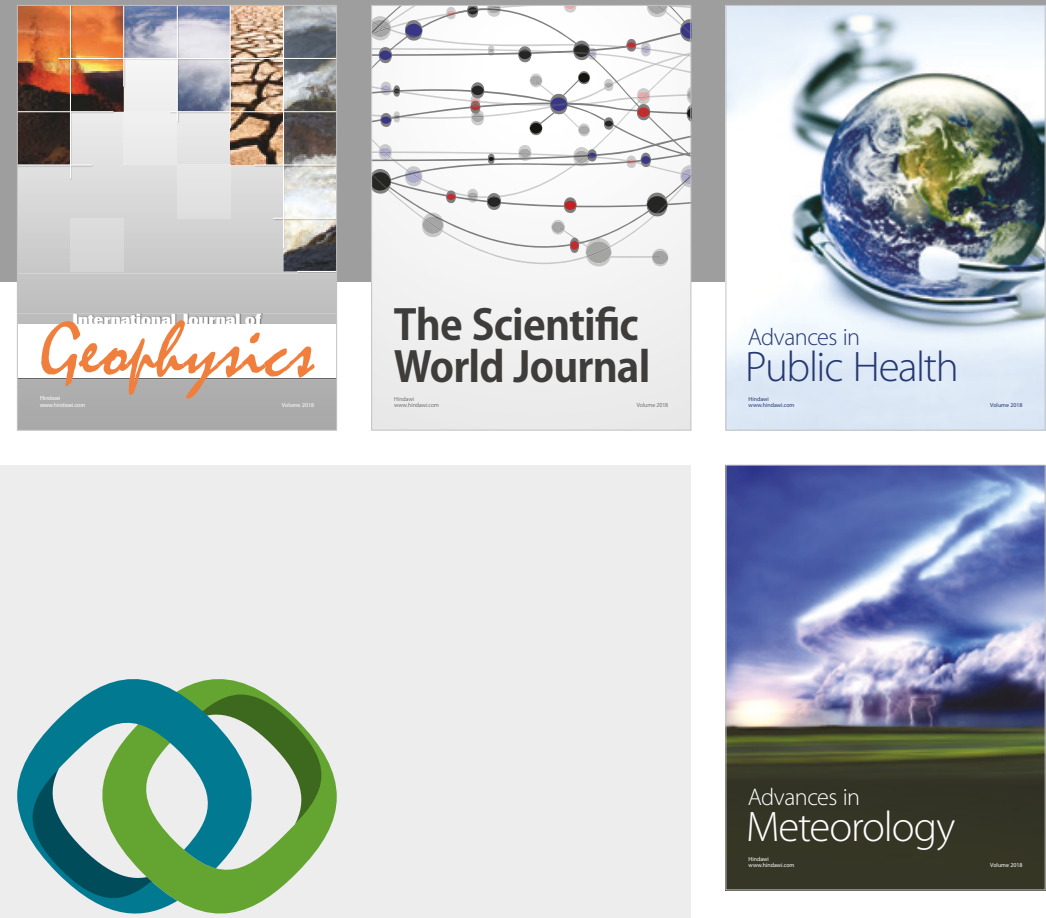

Advan

Public Health

\section{Hindawi}

Submit your manuscripts at

www.hindawi.com
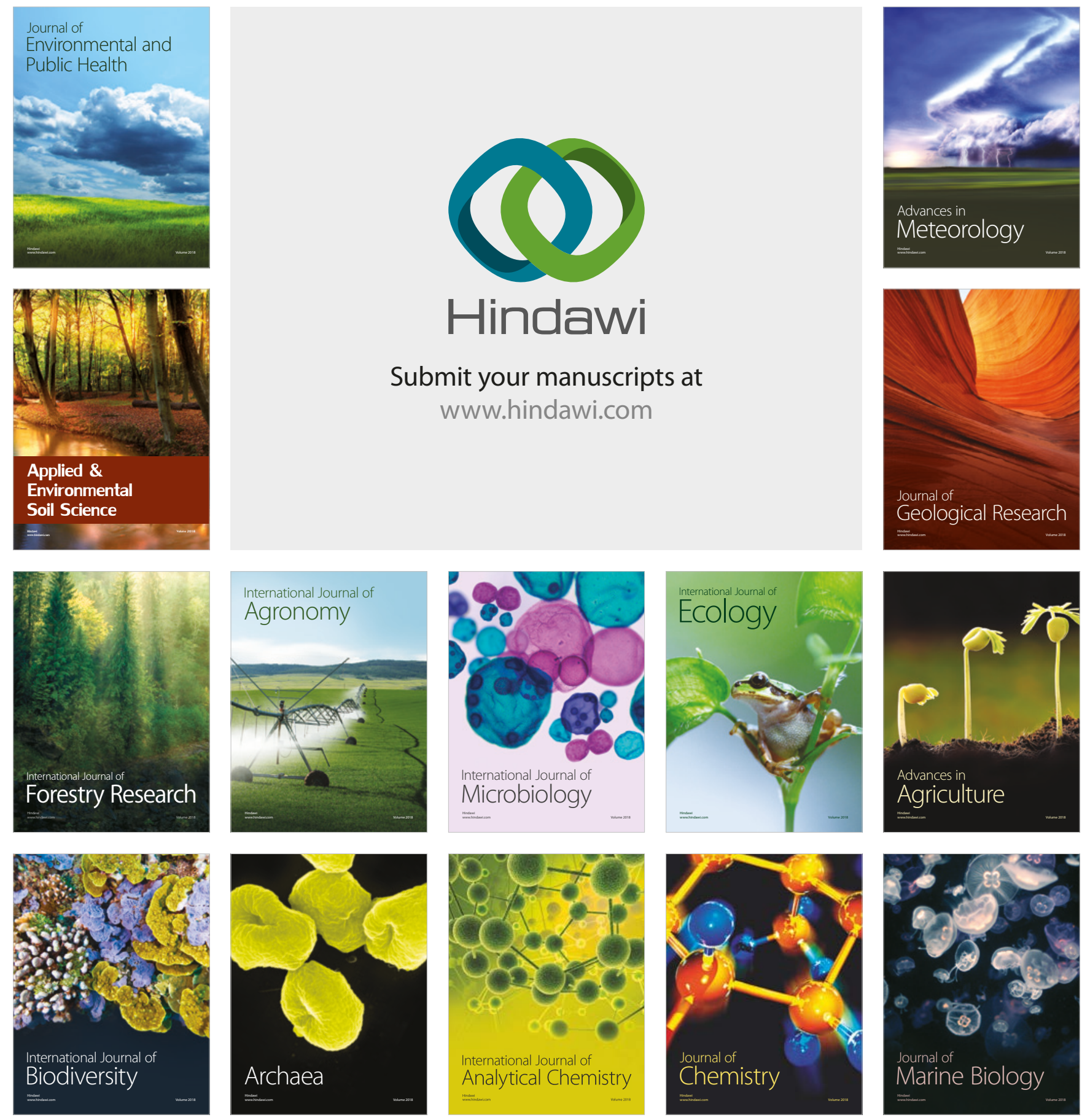